\title{
UPBRINGING POTENTIAL IN FAMILY, THEORETICAL GROUNDS OF ITS CRITERIA AND INDICATORS
}

\section{SUMMARY}

Introduction. A family as a social institution reflects significant changes in the process of society development. With the changes to the social-economic situation the family situation in the Latvian society has become complicated. In the beginning of the 21 st century, the family is affected both by economic and social factors. This results in significant changes to family upbringing process.

Aim of the Study. Analysis of the social-pedagogical problem and formation of criteria and indicators for upbringing potential in the family.

Materials and Methods. Theory method - analysis of scientific literature.

Results. As a result of analysed scientific literature, criteria and indicators of family upbringing potential in the family have been formed, including description of its five levels.

Conclusions. The field of upbringing provides for possibilities to satisfy needs, to improve the values discovered within the field of family life-action, as well as to facilitate formation of sense of belonging.

Key words: family, family upbringing process, family upbringing potential, upbringing field

\section{INTRODUCTION}

A family as a social institution reflects the significant changes in the process of society development. The modern social situation characterised by cumulative transformation processes constantly brings forward new requirements for people maintaining high sense of uncertainty and instability. With the changes to the social-economic situation, the family situation in the Latvian society has become complicated. The family of the beginning of the 21 st century is influenced by economic (inflation, unemployment, increasing employment of women) and social (quality of mutual relations, parents' busyness, attitude towards upbringing, the number of divorces is increasing, the number of childless couples is increasing, family structure changes) factors. This results in significant changes to family upbringing process: cooperation between generations as transfer of pedagogic experience is distorted, attitude towards pedagogic values, which have historically served as basis for upbringing, is changed, mutual relations become reserved and emotionally cold.

The family is a complicated structural object that can function only in a specific relation system. In the modern society of Latvia, the situation is made complicated by the fact that some parents do not wish any interference from outside, they rely only on their experience, knowledge and possibilities; still, they cannot independently solve the caused problems. Two thirds of parents acknowledge that their psychologically-pedagogical knowledge is insufficient that they have insufficient support from specialists (Лодкина, 2006). This contradiction includes both objective and subjective pretext. The objective fact is that modern society covertly fails to support family life-activity; the subjective fact is that the society has limited rights to intervene with the internal 
processes of family life-activity; therefore attitude towards help can be formulated only by members of each family.

The dynamically changing social situation significantly affects the family as the institution of development and unity. Often this influence is negative (Кучмаева, Марыганова, Петряков, Синельников, 2006), promoting violence, incomprehension of the values of life, health, respect (Špona, 2006). At present, the essence of family upbringing is discussed. Modern understanding of family upbringing in scientific literature as one-sided parent influence process has long lost its urgency. Unfortunately specialists offer parents unclear, indeterminate, general phrases instead. The situation becomes chaotic because children feel free and their behaviour is not in contradiction with their internal psychic condition and attitudes; they, however, not always correspond to the declared norms of parent and society behaviour. As a result, when needed, parents (and pedagogues) correct the behaviour, not the attitude. Such situation is pedagogically complicated because one "guilty" person exists and the necessity of hierarchic structure is again substantiated for solving the situation.

\section{AIM OF THE STUDY}

Analysis of the social-pedagogical problem and formation of criteria and indicators for family upbringing potential.

\section{MATERIALS AND METODS}

Analysing scientific literature, it can be concluded that family life-activity is a subjectively interpreted and construed objective reality. Everyday life-activity in a family is planned, organised and specified taking into account the objective situation and the subjective interpretation of the objective situation. Naturally, upbringing in a family is a quality of implementing the pedagogic function in the every day including both subjective and objective aspects. Therefore each family forms its own individual upbringing paradigm which is empirically based. Character of implementing the upbringing process within a family's life activity is revealed by upbringing potential. Whole family life-activity consists of several situations. Family upbringing is a subjective process but it needs objective circumstances and objective conditions for its implementation in life-activity. The objective aspect is upbringing field and its ecology. When parents act in the field of upbringing, a child's development takes place naturally within time and space, thus the child finds there a personally significant activity in compliance with his interests. This results in satisfying his needs, developing attitudes and improving values. Thus family upbringing field is a conditionally limited educational environment where as a result of interaction and cooperation of subjects possibilities are ensured to satisfy needs, improve values and dynamics of personal significance. Thus both the subjective and di-individual aspects overlap in the upbringing field making an entirety. As a di-individual entirety the upbringing field includes cooperation/interaction and rings forward unity as a significant condition. Therefore parents' competency to stimulate a determined progression of social situations is significant by turning life-activity situations in educating situations. Upbringing potential in family life activity includes an aggregate of conditions and means, thus characterises the real level of upbringing process including balanced intellectual and material resources. Thus, all-inclusive mutual cooperation in a family is revealed by implementing upbringing functions.

This unique cooperation in a family combining two or more independently existing forms of being which are characterised by simultaneous severability and non-merging is called by V. Slobodchikov un E. Isayev as a happening that is lived together (событие = co + бытие) 
(Слободчиков, Исаев, 2000). Thus, all-inclusive mutual cooperation in a family is revealed by implementing upbringing functions. Therefore based on findings from scientific literature, cooperation can be brought forward as one of criteria of family upbringing process (Špona, 2006; Mollenhauer, 2003; Kağitçibaşi, 2007; Куликова, 2000; Карабанова, 2007; Пономарев, 2008). By cooperation, a joint and coordinated means of activities, mutual support is understood for achieving the mutual and the personal goal. Therefore this criterion had the following indicators separately determined: first, stability of mutual demands (Mollenhauer, 2003; Куликова, 2000), the demands are understood as determination of each family member's desires and accuracy in choice and use of means of activities. Thus, parents' and children's skills to substantiate, express and maintain desires in compliance with the objective situation. In this aspect, it is important that stability in an objective situation is variable, it can be individually interpreted. Second, participation in joint activities (Špona, 2006; Mollenhauer, 2003; Kaǵitçibaşi, 2007; Куликова, 2000), the participation is understood as facilitating and supporting possibilities, choices and responsiveness in family life-activity. Third, productivity of family life-activity (Mollenhauer, 2003; Kaǵitçibaşi, 2007; Куликова, 2000). The productivity is understood as the subjective feelings by evaluating the emotional dimension of cooperation.

Family as a performer of the upbringing function in the life-activity is characterised by upbringing field, where the life-activity of all family members is naturally organised. A family is a complicated social institution of multi-level mutual relations. Basically these relations are determined by family upbringing field that directly and indirectly affects the emotional wellbeing of all family members which is the prism through which each family member perceives the surrounding world and himself in there (Куликова, 2000). Each family forms its individual upbringing paradigm, which bases on joint values according to T. Kulikova. Values, the planned and projected emotional atmosphere in a family is revealed by upbringing means, methods used by parents and corresponding to the child's age, thus it determines the contents and character of the upbringing field. Stressing whether it will stimulate or slow down the self-upbringing, selfrealisation and autonomy of each family member. Joint values and interests do not ask to refuse from one's individual goals and interests; they rather facilitate cooperation and collaboration (Пономарев, 2008). Thus a family is historically formed as the primary stage of transferring the social experience, mutual emotional and business relations which are utilised productively if based on joint goals and principles. Thus upbringing function used in family life-activity is based on community and unity of relations. On the basis of these finding, family as union was determined as the following criterion of family upbringing (Kaǵitçibaşi, 2007; Куликова, 2000). In this situation, union is understood as composition of family relations which are characterised by unity, belonging (limits) and openness. In order to characterise this criterion, the following indicators were brought forward. First, unity in goals, principles, and values (Куликова, 2000; Овчарова, 2006; Карабанова, 2007), which reveal the progress of family life-activity. Second, balanced internal and external limits of politeness and belonging (Кaǵitçibaşi, 2007; Куликова, 2000), which characterise the acceptable and possible norm and receptiveness towards of the opportunities in the family life-activity composition. Third, unfolding, encouraging, supporting vertical and horizontal dialogue (Куликова, 2000), which characterises the power hierarchy of family life-activity.

The sense of social significance of each family member is stimulated and confirmed in the joint life-activity (Куликова, 2000). Sense of social significance is related with subjective and 
objective aspects of the sense of freedom according to T. Kulikova. A. Špona is of the opinion that freedom is a measure for a person's activity expression (Špona, 2006). Acknowledging one's freedom is the subjective aspect of the freedom phenomenon which is expressed in a creative work, independent decision making and undertaking responsibility for that. In cooperation (action of equal rights and responsibility) when a person self-actualises in life-activity implementing the skills of limiting one's desires and overcoming oneself (Кузьмина, 2007). On the basis of these findings, freedom in family can be brought forward as the following criterion of family upbringing process (Кузьмина, 2007), being the possibility of family members to use their independence, equality and responsibility in compliance with efforts, needs and goals of other family members. In order to characterise this criterion, the following indicators were brought forward: first, equality in rights (Kaǵitçibaşi, 2007), as a characterising measure of expressing and implementing horizontal and vertical desires, which reveals simultaneity and type (in the same manner). Second, independence as a mechanism for adopting decisions. And, third, responsibility as attitude which is characterised by a conscious need to be responsible for one's verbal and non-verbal behaviour and its consequences.

A family is a mediator between a child and the society according to T. Kulikova. Thus, it can be concluded that family upbringing is a transfer of social experience. Therefore a significant subjective condition of family upbringing is family traditions. Traditions have an active character; by being transferred from generation to generation traditions are transformed and therefore can adapt to new social life conditions according to T. Kulikova. Their meaning in the society remains unchanged. They serve as a mechanism for strengthening relations between generations and for transferring social values (Захаров, 1990; Спиваковская, 2000). Possibly therefore they can form new compositions of family relations and upbringing. On the basis of these findings, solidarity can be brought forward as the next criterion of family upbringing being coordination of one's interests, viewpoints and behaviour on the basis of community. Its indicators are, first, attitude towards oneself (Špona, 2006; Kaǵitçibaşi, 2007; Berry, Poortinga, Segall, Dasen, 2002) as maintenance of one's interests and habits and their coordination with other family members, as well as support of interests and habits of other family members. Second, attitude towards others (Klēgeris, 1959; Mollenhauer, 2003; Bronfennbrenner, 1993; Мид, 2004) as a uniqueness of aggregate viewpoints, activities, behaviour which have been deliberately begun, organised, maintained and attended in a family.

Upbringing process as a complex, dynamic and progressive composition (a composition is a layout of components and their mutual connection) is implemented in life activity if these criteria and indicators mutually interact and constantly develop. From pedagogical aspect, these are the very components to be the basic criteria for satisfying family member's needs, improving the personal significance of values, development of attitudes and choice of behaviour form in lifeactivity.

\section{RESULTS}

The formed criteria for family upbringing potential and their indicators are summarised and described in the offered table (see Table 1). The indicators had a five-level description formed that allows interpret the contents and form of family upbringing process in a pedagogically correct manner. 
Table 1. Criteria and Indicators for Characterising Family Upbringing Potential in a Family

\begin{tabular}{|l|l|}
\hline \multicolumn{1}{|c|}{ Criterion } & \multicolumn{1}{c|}{ Indicator } \\
\hline Family as union & Unity in principles, goals and values \\
\cline { 2 - 2 } & Balanced internal and external limits of belonging and politeness \\
\cline { 2 - 2 } & Open, encouraging, supporting vertical and horizontal dialogues \\
\hline \multirow{2}{*}{$\begin{array}{l}\text { Cooperation } \\
\text { in family }\end{array}$} & Stability of mutual demands \\
\cline { 2 - 2 } & Participation in the family's joint activity \\
\cline { 2 - 2 } & Productivity of family life-activity \\
\hline Freedom in family & Equality \\
\cline { 2 - 2 } & Independence \\
\cline { 2 - 2 } & Responsibility \\
\hline Solidarity in family & Attitude towards oneself \\
\cline { 2 - 2 } & Attitude towards others \\
\hline
\end{tabular}

In compliance with the described criteria and indicators, the author of the articles offers to name the implementation of upbringing process in the family life-activity (according to Table 1): - family upbringing within A level - uniform family,

- family upbringing within B level - stable family,

- family upbringing within $\mathrm{C}$ level - confused family,

- family upbringing within 0 level - indifferent family,

- family upbringing within D level - inattentive family.

The following description forms a description of the uniform family (A level). Family members have a single goal, principles and values. The internal and external limits of belonging and politeness are explicitly balances and flexible. The vertical and horizontal dialogue is explicitly open, encouraging, supporting. Parents and children are able to substantiate, express and maintain desires in compliance with the objective situation. The vertical and horizontal responsiveness and work activity is flexible. Satisfaction with the cooperative family life-activity. The horizontal and vertical expression and implementation of desires is equal in rights. The horizontal and vertical independence in decision making and activity. All undertake responsibility for performance of the adopted decisions. Habits exist to coordinate one's interests and behaviour with other family members. Joint interests, viewpoints and behaviour have been strengthened in special family traditions.

The following description forms a portrayal of the stable family (B level). Family members partially have a single goal, and/or principles and/or values. Balanced internal and external limits of belonging and politeness. Open, encouraging, supporting vertical and/or horizontal dialogue. Open, encouraging, supporting vertical and/or horizontal dialogue. Parents and children not always are able to substantiate, express and maintain desires in compliance with the objective situation. The vertical and/or horizontal responsiveness and work activity is imitated. Satisfaction with the cooperative family life-activity is not always present. The horizontal and/or vertical expression and partial implementation of desires is equal in rights. The horizontal and/or vertical partial independence in decision making and activity. Adults undertake responsibility for performance of the adopted decisions. Partially developed habits exist to coordinate one's interests and behaviour with other family members. Joint interests, viewpoints and behaviour have been strengthened in some family traditions. 
The following description forms a portrayal of the confused family (C level). Family members do not have unity in principles, goal and values. Unbalanced internal and external limits of belonging and politeness. Partially open, encouraging, supporting vertical and/or horizontal dialogue. Parents and children are unable to substantiate, express and maintain desires in compliance with the objective situation. The vertical and/or horizontal responsiveness and work activity is manipulative. Dissatisfaction with the cooperative family life-activity. The horizontal and/or vertical expression and implementation of desires is partially equal in rights. The vertical and/or horizontal decision making and activity is situational. Often, the taken decisions are not performed. Habits to coordinate one's interests and behaviour with other family members are not developed. Joint interests, viewpoints and behaviour have not been strengthened in family traditions.

The following description forms a portrayal of the indifferent family (0 level). Family members do not know each other's principles, goal and values. The internal and external limits of belonging and politeness are indifferent and unclear. A vertical monologue exists. Opinions are not expressed in a dialogue. Parents express, substantiate and maintain desires in compliance with the objective situation. The vertical and/or horizontal responsiveness does not exist and the work activity is stimulated by a sometimes-expressed suggestions. There is no cooperative lifeactivity in the family. The horizontal and/or vertical expression and implementation of desires are suppressed. The vertical influence on decision making and activity is dominant. Joint decisions are not made and joint life-activity is seldom. They do not know each other's habits and interests in the family. Joint interests, viewpoints and behaviour are situational. Family traditions are not purposefully formed.

The following description forms a portrayal of the inattentive family (D level). Family members ignore each other's principles, goal and values. The internal and external limits of belonging and politeness are unclear and closed. A situational vertical monologue is dominant, there is no dialogue. Desires are not expressed, substantiated and maintained in compliance with the objective situation. The vertical and/or horizontal responsiveness and work activity is competitive. The cooperative life-activity in the family is ignored. The vertical and horizontal expression and implementation of desires is ignored. The horizontal and/or vertical decision making and activity is suppressed. Joint decision making and their implementation in joint life-activity is avoided. Each other's habits and interests are criticised in the family. Interests, viewpoints and behaviour differ. Intolerance and criticism of joint activity.

\section{CONCLUSIONS}

- A family as a historical, social and individual unique life-activity form is a significant aspect for stimulating a person's (children and adults) uniqueness (Куликова, 2000), universality (Слободчиков, Исаев, 2000), autonomy (Maslo, 2003; Мухина, 2000; Олпорт, 2002; Козлов, 2007; Нартова - Бочавер, 2008), and self-upbringing (Козлов, 2007). Each family is unique, its life-activity is characteristic of a definite historic period, social and cultural environment. However, each family is formed of specific people who influence the uniqueness of others by their own uniqueness. Therefore, as quintessence, the summary expression of all criteria and indicators that can be observed, understood, and characterised, both as an ideal model for family upbringing potential in the specific society, as well as to find the real model of upbringing potential in the specific society.

- The field of upbringing provides for possibilities to satisfy needs, to improve the values 
discovered within the field of family life-action, as well as to facilitate formation of sense of belonging. The field of upbringing is a wider concept on life-activity because it includes a balanced psychic, physical and social component. Satisfaction of needs can take place only in mutual inter-relations, thus upbringing is implemented mainly within the process of practical or intellectual activity cooperation (Špona, 2006; Lieǵeniece, 1999). Subjective senses determine the level of satisfaction of these needs that is the indicator of personal emotional satisfaction. Only in case the emotional background stimulates subjective emotional satisfaction, a person's attitude toward himself, others and things is self-regulated, responsible and the person is autonomous. Thus, the subjective sense of satisfaction - dissatisfaction of these basic needs affects the individual evaluation of family members' values, which results in the value being improved and becoming or failing to become personally significant. So, family life-activity experience is formed which is inherited from generation to generation.

\section{REFERENCES}

1. Klēǵeris, N. (1959) Tradīciju un paradumu loma bērnu audzināšanā skolā un ǵimenē [Role of Traditions and Habits in Upbringing of Children at School and in Family]. Rīga: Latvijas Valsts izdevniecība, 9.-60. 1pp. (in Latvian).

2. Lieǵeniece, D. (1999) Kopveseluma pieeja audzināšanā [Approach of Joint-Entirety to Upbringing]. Rīga: RaKa, 32.-124. lpp. (in Latvian).

3. Maslo, E. (2003) Mācīšanās spēju pilnveide [Development of Learning Skills]. Rīga: RaKa, 10.-15., 42.-43. 1pp. (in Latvian).

4. Špona, A. (2006) Audzināšanas process teorijā un praksē [Upbringing Process in Theory and Practice]. Rīga: RaKa, 91.-144. lpp. (in Latvian).

5. Bronfenbrenner, U. (1993) Die Ökologie der menschlichen Entwicklung. Natürliche und geplante Experimente [Human Development Ecology. Natural and Planned Experiments]. Frankfurt am Main: Fischer Taschenbuch Verlag GmbH, S. 19-59, 199-268 (in German).

6. Mollenhauer, K. (2003) Vergessene Zusammenhänge. Über Kultur und Erziehung [Forgotten Backgrounds. About Culture and Upbringing]. Weinheim und München: Juventa Verlag, S. 114-154 (in German).

7. Berry, J., Poortinga, Y., Segall, M., Dasen, P. (2002) Cross - Cultural Psychology. Research and Applications. Cambridge: Cambridge University Press, p. 59-64, 248-448.

8. Kaǵitçibaşi, Ç. (2007) Family, Self, and Human Development across Cultures. Theory and Applications. 2nd edition. London: Lawrence Erlbaum Associates Publishers, p. 27-367.

9. Нартова - Бочавер, С. (2008) Человек суверенный: Психологическое исследование субъекта в его бытии [Sovereign Man: Psychological Research of a Subject in its Being]. Санкт - Петербург: Питер, с. 53-167 (in Russian).

10. Захаров, А. (1990) Как предупредить отклонения в поведении ребенка [How to Avoid Deviations in Child's Behaviour]. Москва: Эксмо, с. 47 (in Russian).

11. Лодкина, Т. (2006) Социальная педагогика. Защита семьи и детства [Social Pedagogy. Protection of Family and Childhood]. Москва: АКАДЕМІА, с. 28-41 (in Russian).

12. Карабанова, О. (2007) Психология семейных отношений и основы семейного консультирования [Psychology of Family Relations and Elements of Family Consultations]. Москва: ГАРДАРИКИ, c. 117-244 (in Russian). 
13. Кузьмина, Е. (2007) Психология свободы. Теория и практика [Freedom Psychology. Theory and Practice]. Санкт - Петербург: Питер, с. 120-174 (in Russian).

14. Куликова, Т. (2000) Семейная педагогика и домашнее воспитание [Family Pedagogy and Home Upbringing]. Москва: АКАДЕМІА, с. 22-139 (in Russian).

15. Кучмаева, О., Марыганова, Е., Петрякова, О., Синельников, А. (2006) Влияние экономических показателей на воспитательный потенциал семьи. Научные труды научно-исследовательского института семьи и воспитания [Influence of Economic Indicators on the Potential of Family Upbringing. Scientific Works of Scientific Research Institute of Family and Education]. Москва: Государственный НИИ семьи и воспитания, с. 58-71 (in Russian).

16. Козлов, В. (2007) Работа с кризисной личностью [Work with a Personality in Crisis]. Москва: Психотерапия, с. 17-139 (in Russian).

17. Мид, М. (2004) Культура и преемственность. Исследование конфликта между поколениями [Culture and Succession. Research of Conflict between Generations]. Молодежнная субкультура. Москва: Гранд, с. 478-504 (in Russian).

18. Мухина, В. (2000) Возрастная психология [Age Psychology]. Москва: АКАДЕМІА, с. 50-104 (in Russian).

19. Овчарова, Р. (2006) Родительство как психологический феномен [Parenting as Psychology Phenomenon]. Москва: Москвский психолого-социальный институт, с. 7-178 (in Russian).

20. Олпорт, Г. (2002) Становление личности [Becoming of Personality]. Москва: Смысл, с. 242-248 (in Russian).

21. Слободчиков, В., Исаев, Е. (2000) Психология развития человека [Psychology of Human Development]. Москва: ШКОЛЬНАЯ ПРЕССА, с. 254-284 (in Russian).

22. Спиваковская, А. (2000) Психотерапия: игра, детство, семья [Psychotherapy: Game, Childhood, Family]. Volume 2. Москва: ЭКСМО - Пресс, с. 11-216 (in Russian).

23. Пономарев, Н. (2008) Связи с общественностью: социально - психологические аспекть [Relations with the Public: Social-Psychological Aspects]. Санкт - Петербург: Питер, с. 7-54 (in Russian).

\section{Assistant Professor Mg. paed. Dace Medne}

Jāzeps Vītols Latvian Academy of Music

Address: Kr. Barona iela 1, Rīga, LV-1050

Phone: +371 29255656

E-mail: dace_medne@tvnet.lv 